\title{
Implementasi Nilai Pancasila di Era Disrupsi Pada Proses Pembelajaran Anak Sekolah Dasar
}

\author{
Mita Maulani ${ }^{1 *}$, Dinie Anggraeni Dewi ${ }^{2}$ \\ ${ }^{1,2}$ Universitas Pendidikan Indonesia Kampus Daerah Cibiru, Indonesia \\ *email: mitamaulani@upi.edu
}

\begin{abstract}
This study aims to create and apply Pancasila values to the country in line with the rapidly developing technological developments. This research method uses qualitative methods with literature methods. This research information is by reading several journals and books and finding out about the application of the value of Pancasila with this era of disruption. The results showed that in this era of disruption, the value of Pancasila needs to be implemented with the development of technology for elementary school children in Indonesia to continue to obey and live in accordance with applicable rules and not change its meaning. In implementing the Pancasila values, it is hoped that elementary school children will continue to love the nation and the country, have good morals, have noble character and have good manners.
\end{abstract}

Keywords: Implementation, Pancasila Values, Era of Disruption

\begin{abstract}
Abstrak:Penelitian ini bertujuan untuk menciptakan dan menerapkan nilai pancasila terhadap negara seiring dengan perkembangan teknologi yang berkembang pesat. Metode penelitian ini menggunakan metode kualitatif dengan metode literatur. Informasi penelitian ini yaitu dengan membaca beberapa jurnal dan buku serta mencari tahu mengenai penerapan antara nilai pancasila dengan era disrupsi ini. Hasil penelitian menunjukkan bahwa dalam era disrupsi ini nilai pancasila perlu di implementasikan dengan perkembangan teknologi terhadap anak sekolah dasar di Indonesia tetap mentaati dan menjalankan kehidupan sesuai dengan aturanaturan yang berlaku serta tidak merubah maknanya. Dalam penerapan nilai pancasila ini mengharapkan anak sekolah dasar tetap mencintai bangsa dan negara, memiliki akhlak yang baik, berbudi pekerti yang luhur dan memiliki sopan santun.
\end{abstract}

Kata Kunci: Implementasi, Nilai Pancasila, Era Disrupsi

\footnotetext{
Copyright (c) 2021 The Authors. This is an open access article under the CC BY-SA 4.0 license (https://creativecommons.org/licenses/by-sa/4.0/)
}

\section{PENDAHULUAN}

Pancasila merupakan sebuah pondasi dari bangsa dan negara Indonesia yang memiliki tujuan untuk membangun dan menyelesaikan berbagai permasalahan yang terdapat dalam bangsa dan negara baik pada sektor ekonomi, sosial, politik, pendidikan serta masalah-masalah yang terjadi di kehidupan bermasyarakat (Suharno, S. 2020). Mengingat manusia dihadapkan dengan era globalisasi yang ditandai dengan kemajuan teknologi yang sangat melesat yang memiliki dampak bagi warga Indonesia mengenai pancasila karena dengan itu dapat menggoyahkan bahkan menggeser nilai-nilai pancasila 
dan nilai-nilai dalam negeri karena tergantikan dengan nilai-nilai budaya asing yang masuk ke negara Indonesia.

Era disrupsi merupakan suatu dampak dari perubahan revolusi industri 4.0 yang merupakan suatu era yang dipenuhi dengan tantangan. Pada era ini ditandai dengan semakin melesatnya perkembangan teknologi (Fadlila Rachman, 2020). Semakin berkembangnya banyak perubahan-perubahan yang dialami sehingga membuat pengaruh yang semakin berubah berbeda dengan keadaan sebelumnya, mengingat pancasila merupakan ideologi bangsa dan negara yang memiliki fungsi sebagai suatu pedoman dalam bersikap dan bertingkah laku dalam semua aspek-aspek kehidupan.

Pada umumnya masyarakat hanya menerapkan kepada anak mengenai penghafalan pancasila saja tetapi tidak dengan penerapannya dalam kehidupan seharihari yang membuat generasi penerus bangsa memiliki kecenderungan kurang mencintai akan tanah air dan budaya asli dari negaranya sendiri. Anak usia dini pada era disrupsi ini sudah banyak kita temui bahwa anak-anak sudah pandai menggunakan gadget padahal penggunaan gadget itu tidak boleh untuk anak-anak karena selain akan menirukan orang dewasa penggunaan gadget ini pun akan menghambat perkembangan tubuh anak baik dari segi fisik atau motorik anak. Orang tua sangat berperan aktif dalam menerapkan nilai pancasila yang dapat di tanamkan pada anak sedini mungkin supaya anak menjadi generasi penerus bangsa yang memiliki kesesuaian dan menjadi harapan bangsa dan negara Indonesia ini.

Kolaborasi penerapan nilai pancasila pada era disrupsi ini sangat penting untuk diterapkan baik pada bidang pendidikan, sosial dan lingkungan rumah. Karena dengan kolaborasi ini dapat menyesuaikan dan menyeimbangkan nilai-nilai pancasila tanpa merubah sedikitpun aturan-aturan dalam hidup yang sesuai dengan nilai pancasila. Menurut Atiah (2020), sektor pendidikan yang sangat berperan penting dalam menciptakan generasi yang memiliki akhlak yang baik, sopan santun, dan dengan membangun moral bangsa di era disrupsi yang telah menggunakan semua bidang tidak luput dengan teknologi.

Teknologi yang berkembang telah menciptakan berbagai fitur-fitur yang sangat memudahkan manusia untuk melakukan berbagai hal dari mulai komunikasi, informasi serta lainnya. Banyak manfaat yang dapat diambil dengan perkembangan teknologi yang melesat ini tetapi tidak memungkiri banyak pula dampak negatif apalagi bagi kalangan 
anak-anak. Penyalahgunaan teknologi membuat anak seusia dini berperilaku mengikuti orang dewasa bahkan budaya barat yang membuat kecintaan terhadap kebudayaan Indonesia sedikit memudar, bahkan etika sopan santun dan karakter meniru orang dewasa ini disebabkan oleh kemajuan teknologi yang semakin berkembang dengan banyak fitur seperti video-video yang terdapat dalam sebuah aplikasi yang dapat merusak anak.

\section{METODE}

Penelitian ini menggunakan metode jenis literatur. Penelitian ini berisi tentang implementasi nilai-nilai pancasila dalam proses pembelajaran anak sekolah dasar di eradisrupsi dengan menelusuri sumber-sumber pustaka sehingga ditemukan tentang gambaran mengenai bagaimana penerapan yang dapat dilakukan pada generasi milenial seperti saat ini supaya peserta didik dapat memiliki karakter yang sesuai dengan karakteristik pancasila yang dapat diamalkan serta diterapkan dalam kehidupan berbangsa dan bernegara. Analisis ini berupa analisis deskriptif dengan melalui pendekatan kualitatif, pada metode deskriptif ini menjelaskan mengenai fakta-fakta yang diuraikan dan bertujuan untuk memberikan pengetahuan, pemahaman dan penjelasan .

\section{HASIL DAN PEMBAHASAN}

\section{A. Nilai-Nilai Yang Terkandung Dalam Pancasila}

Pancasila adalah suatu dasar negara yang terdiri dari lima sila dan pancasila memiliki suatu nilai-nilai yang terdiri dari lima sila yaitu berdasarkan kepada Tuhan, kemanusiaan, persatuan, kerakyatan dan keadilan. Banyak yang mengatakan bahwa pancasila harus dijadikan sebagai tumpuan kehidupan yang dapat diterapkan atau dilaksanakan dalam kehidupan sehari-hari terlebih kepada anak usia dini (Sulianti, Efendi dan Sa'diyah, 2020). Anak usia dini harus ditanamkan nilai pancasila karena mereka merupakan sebuah generasi penerus bangsa yang nantinya akan menjadi generasi yang diharapkan oleh bangsa dan negara Indonesia. Asmaroini (2016) menyatakan bahwa nilai pancasila sangat dijadikan sebagai pandangan hidup bernegara yang memiliki tujuan tertentu dalam mengembangkan motivasi, serta dapat dijadikan dalam kehidupan dasar seseorang. Penerapan ini sangat disesuaikan dengan undang-undang yang berlaku di negara Indonesia. Mengingat sebagai warga negara yang baik perlu menerapkan nilainilai pancasila di setiap sektor serta dalam kehidupan sehari-hari.

Sebuah pendidikan dikatakan paling penting apabila mengandung nilai-nilai pancasila karena nilai-nilai pancasila merupakan sebuah tameng yang penting dalam 
menghadapi tantangan di era disrupsi ini. Semakin berkembang teknologi maka akan semakin masuk kebudayaan-kebudayaan asing yang masuk ke Indonesia melalui banyak sekali media yang dapat mengunggah situs-situs berbagai macam. Indonesia merupakan bangsa yang berlimpah akan kekayaan alamnya serta keanekaragaman budaya, bahasa, suku dan agama. Paradigma pertahanan Indonesia memuat nilai-nilai pancasila yang tercantum dalam pembukaan UUD RI 1945 (Suharno, 2020).

Terdapat beberapa nilai-nilai yang memuat dalam sila-sila pancasila sebagai berikut:

\section{Sila Pertama}

Sila pertama ini memuat nilai-nilai mengenai negara yang harus didirikan sebagai tujuan makhluk hidup mengingat akan adanya Tuhan Yang Maha Esa, oleh karena itu pelaksanaan dan penerapan ini sesuai dengan moral, politik, pemerintah, hukum serta aturan yang terdapat dalam undang-undang yang harus diterapkan dan ditanamkan dalam diri seseorang.

\section{Sila Kedua}

Sila kedua mengandung nilai bahwasanya masyarakat harus dapat menjunjung tinggi segala bentuk yang membuat manusia memiliki suatu adab selain itu pada sila ini terkandung nilai akan kesadaran dan sikap moral dan tingkah laku yang telah sesuai dengan norma yang berlaku dan semakin perkembangan teknologi ini nilai moral pancasila harus semakin ditanamkan.

\section{Sila Ketiga}

Manusia merupakan makhluk sosial yang harus bersosialisasi dengan masyarakat lain dan saling menghormati antar suku, agama, budaya dan golongan. Serta menerapkan toleransi yang sangat tinggi dalam penerapan bagi anak usia dini.

\section{Sila Keempat}

Masyarakat merupakan pokok negara, karena negara itu terdiri dari rakyat dan kembali lagi kepada rakyat. Dalam sila ini terdapat sebuah nilai yang menjadikan seseorang demokratis dan yang diterapkan oleh masyarakat (O3Tugas Pancasila 1 Winanda Marasoli Maksum (1744390026) (1), n.d.).

\section{Sila Kelima}

Dalam sila ini harus terwujud beberapa nilai keadilan seperti dalam bernegara, keadilan terhadap negara dan keadilan antara negara satu dan negara lainnya. Maulida (2019), mengatakan bahwa pancasila merupakan suatu pondasi negara yang dapat 
dijadikan sebuah pandangan hidup oleh bangsa negara Indonesia. Selain itu ada nilai karakter yang dapat diterapkan kepada anak sekolah dasar di era disrupsi ini seperti tercantum dalam sila-sila tersebut yaitu:

\section{Nilai Ketuhanan}

Ada beberapa nilai karakter dalam sebuah ketakwaan dan kepercayaan terhadap sang pencipta, bebas untuk memiliki agama, memiliki nilai toleransi antar umat beragama, dan memiliki rasa kecintaan terhadap Tuhan Yang Maha Esa, diterapkannya sikap toleransi pada anak usia dini ini sangat penting agar tertanam dalam dirinya untuk menghargai semua orang karena semua orang itu berbeda-beda.

\section{Nilai Kemanusiaan}

Terdapat beberapa nilai karakter yang dapat ditanamkan kepada anak di generasi seperti sekarang ini yaitu menumbuhkan persatuan, selalu bersama, mencintai bangsa, dapat mencintai tanah air, dapat bersikap adil dan memiliki adab dalam berkehidupan, berbangsa dan bernegara.

\section{Nilai Persatuan}

Pada nilai ini terkandung karakter sama dengan nilai kemanusiaan termasuk dengan karakter-karakter yang ditanamkannya.

\section{Nilai Kerakyatan}

Adanya kandungan karakter dalam kerakyatan dengan menanamkan musyawarah untuk mufakat, selalu demokratis dalam segala hal dan selalu bijaksana dalam segala sesuatu baik itu bertindak dalam permasalahan maupun bertindak dalam segala urusan yang dihadapi.

\section{Nilai Keadilan}

Penanaman karakter dalam nilai ini memuat mengenai keadilan baik dalam keadilan sosial, selalu melakukan keadilan dalam kekeluargaan dan selalu bergotong royong dalam melakukan berbagai hal.

\section{B. Proses Pembelajaran}

Kegiatan berlangsungnya proses pembelajaran yaitu dengan adanya guru dan peserta didik serta fasilitas yang memadai baik dari dalam ruangan kelas maupun di luar ruangan. Dewi \& Nur (2014) mengatakan bahwa belajar merupakan sebuah proses yang tidak akan dapat dipisahkan dari kehidupan seseorang, karena belajar manusia bisa menanamkan kemampuan dalam diri yang dimiliki oleh peserta didik. Tanpa proses 
pembelajaran manusia tidak akan bisa memenuhi segala kebutuhan hidupnya, kegiatan pembelajaran dapat dilaksanakan kapanpun dan dimanapun berada.

Sistem pembelajaran ini berfokus kepada tiga unsur yaitu adanya peserta didik, kegiatan pembelajaran serta keadaan belajar. Karena kegiatan pembelajaran dimana kedudukan pendidik sudah dipandang sangat baik dan telah dianggap sebagai pengelolaan yang dapat membantu siswa. Proses pembelajaran mempunyai beberapa tujuan diantaranya yaitu dapat menyampaikan materi dengan baik, materi yang disampaikan dapat dipahami, selalu memberikan hal yang terbaik untuk peserta didik. Siswa sekolah dasar yang dinyatakan oleh NAEYC (National Association For The Education Of Young Children) merupakan anak yang berada pada rentang usia 6-12 tahun, sedangkan proses pembelajaran mempunyai beberapa tujuan diantaranya yaitu dapat menyampaikan materi dengan baik, materi yang disampaikan dapat dipahami, selalu memberikan hal yang terbaik untuk peserta didik, karena guru yang tulus mengajarkan dengan baik dan ikhlas menuntun para siswa yang bertajuk semangat juang untuk negara (Hatim, 2020).

Dalam sistem pembelajaran ini ada tiga faktor pendukung seperti adanya peserta didik, pendidik, dan terjadinya proses pembelajaran. Pendidik memiliki kedudukan khusus bagi peserta didik karena tanpa adanya pendidik peserta didik tidak dapat menimba ilmu dengan benar. Tentu saja terdapat komponen atau unsur terjadinya pembelajaran yaitu:

1) Tujuan Pendidikan

Pendidikan memiliki tujuan yang dilaksanakan melalui proses pembelajaran seperti peserta didik diharapkan mendapatkan sebuah pengalaman dari kegiatan pembelajaran, serta tujuan untuk mengubah perilaku peserta didik menjadi seseorang yang lebih baik.

2) Bahan Pembelajaran

Bahan ajar pada proses pembelajaran ini bertujuan untuk memberikan beberapa materi yang akan dipelajari untuk anak-anak di sekolah, supaya anak-anak dapat memahami materi, menambah ilmu pengetahuan peserta didik dan siswa memiliki keterampilan lainnya.

3) Aktivitas Pembelajaran 
Dalam aktivitas belajar peserta didik diharapkan selalu terlibat antara interaksi yang dilakukan oleh pendidik dan peserta didik dengan mengikuti bahan ajar yang diberikan oleh pendidik.

4) Program

Program atau suatu cara yang dapat digunakan untuk tercapainya sebuah tujuan yang akan dicapai karena dalam kegiatan pembelajaran perlu cara yangdapat digunakan untuk menggapai suatu tujuan.

5) Alat

Alat yang dipergunakan untuk membuat segala sesuatu hal yang ingin dicapai baik untuk peserta didik maupun pendidik itu sendiri.

6) Sumber Pembelajaran

Yaitu sebuah sarana untuk menyampaikan materi atau untuk memperlancar terjadinya kegiatan belajar mengajar yang sedang berlangsung. Selain itu sumber belajar dapat memberikan segala sesuatu kebutuhan pembelajaran baik secara fasilitas, atau ruang lingkup lainnya.

7) Penilaian

Penilaian yaitu suatu catatan yang telah dilakukan oleh seseorang atau suatu kegiatan untuk menentukan bagaimana nilai dari kegiatan tersebut apakah sudah tepat, agar kedepannya dapat dijadikan sebagai catatan pembelajaran akan kesalahan yang tidak akan diulang kembali.

\section{C.Implementasi Nilai Pancasila Dalam Kegiatan Pembelajaran Anak Tingkat Sekolah Dasar Di Era Disrupsi}

Penerapan nilai pancasila dalam aktivitas belajar untuk peserta didik terutama pada peserta didik sekolah dasar diterapkan akan penanaman sikap mencintai tanah air yang selalu dibiasakan dengan pembiasaan sikap seperti pendidik membimbing dan mengarahkan peserta didik pada kegiatan upacara bendera yang selalu dilakukan setiap hari Senin, guru membimbing dan mengarahkan anaknya untuk menyanyikan lagu kebangsaan Indonesia Raya agar anak memiliki nasionalisme dalam rangka menumbuhkan nilai-nilai pancasila yang tertanam dalam diri peserta didik terutama anak seusia sekolah dasar (Asmaroini, 2016). Penanaman nilai-nilai itu dapat melalui pendidikan tentang pancasila di berbagai jenjang pendidikan terutama pada jenjang pendidikan sekolah dasar (Kristiono, 2017). 
Era disrupsi merupakan zaman dimana terjadinya perubahan yang sangat signifikan terkait perkembangan teknologi yang berkembang pesat. Pengaruh teknologi dan komunikasi pada era disrupsi ini semakin bertambah tinggi penggunaan teknologi dan media sosial yang digunakan. Media sosial banyak dipergunakan oleh hampir seluruh manusia yang ada di bumi serta tidak memandang usia baik dari usia dini, anak-anak, remaja, dewasa serta lansia. Di era disrupsi ini harus adanya antara kolaborasi penerapan nilai pancasila karena di era ini semakin berkembang teknologi serta semakin banyaknya budaya asing yang masuk ke Indonesia maka tak heran jika sebagian masyarakat Indonesia sudah mulai luntur akan kecintaannya terhadap budaya Indonesia serta telah menghilangkan nilai etika sopan santun yang merupakan ciri seorang berkarakter.

Menurut Khosiah (2020), implementasi nilai-nilai ini harus telah tertanam dalam diri semua warga negara Indonesia terutama kepada anak-anak di generasi sekarang karena dengan semakin berkembangnya teknologi serta perubahan zaman anak-anak kurang mencintai negaranya sendiri dengan menanamkan nilai-nilai pancasila dalam proses pembelajaran diharapkan penerus bangsa dapat mewujudkan cita-cita dan tujuan bangsa. Upaya pelaksanaan nilai-nilai pancasila ini diperuntukkan supaya peserta didik memiliki karakter yang diharapkan oleh bangsa Indonesia, karena implementasi nilainilai pancasila ini sangat penting, penanaman nilai-nilai ini dapat dilaksanakan pada saat proses kegiatan pembelajaran dimana peran pendidik dapat membimbing dan mencontohkan melalui kegiatan proses pembelajaran akan penerapan dan pelaksanaan nilai-nilai pancasila tersebut. Wahyono (2018), mengatakan bahwa nilai pancasila perlu ditanamkan bagi generasi-generasi penerus bangsa di masa depan.

Berbagai upaya atau cara untuk menguatkan akan nilai pancasila yang selalu diterapkan dalam proses pembelajaran. Aktivitas atau kegiatan yang selalu diterapkan guna untuk menguatkan karakter dalam menjalankan nilai pancasila dan dapat diterapkan oleh anak peserta didik dalam kehidupan sehari-hari seperti dalam bermusyawarah untuk memilih struktur kelas, bekerja sama untuk berdiskusi dan selalu melakukan berbagai kegiatan yang membawa hal kebaikan bagi dirinya maupun orang lain (Fadilah, 2019).

Dalam kehidupan tidak lepas dengan berbagai macam masalah yang akan dihadapi terutama pada perkembangan zaman yang semakin melesat membuat banyaknya perubahan yang terjadi, masalah seperti melunturnya akan kecintaan terhadap negara sendiri, hilangnya sikap saling menghargai, kurang tertanamnya sikap-sikap yang 
mencerminkan sesuai dengan aturan yang berlaku pada anak. Penerapan nilai pancasila untuk peserta didik melalui kegiatan pembelajaran, dimana siswa sedang aktif melakukan pembelajaran di situ tertanam nilai pancasila. Para pendidik atau guru dalam memberikan metode dan materi pembelajaran terhadap siswa agar terciptanya proses pembelajaran yang menyenangkan bagi peserta didik.

Implementasi nilai-nilai pancasila dalam kegiatan pembelajaran pada anak sekolah dasar yaitu sebagai berikut:

\section{Ketuhanan Yang Maha Esa}

Penanaman nilai pancasila untuk yang pertama yaitu disaat kegiatan pembelajaran berlangsung siswa selalu melakukan perilaku yang baik seperti ketika berpapasan dengan guru, selalu mengawali pembelajaran dengan pembacaan doa-doa, guru membimbing peserta didik untuk beribadah.

\section{Kemanusiaan Yang Adil dan Beradab}

Penanaman nilai pada sila ke dua ini yaitu peserta didik belajar saling menghormati antara teman baik kepada orang yang lebih tua ataupun orang yang lebih muda, guru selalu mencontohkan pada saat kegiatan pembelajaran berlangsung dengan selalu bersikap adil terhadap peserta didik, seperti contoh tidak membedakan anak baik itu anak orang kaya maupun tidak, tidak membedakan murid dari fisik, melakukan kegiatan piket dengan adil serta membagi tugas kelompok dengan sama rata.

3. Persatuan Indonesia

Penanaman nilai-nilai pancasila untuk sila ke tiga bagi para peserta didik disaat kegiatan proses pembelajaran yaitu dengan menanamkan rasa cinta tanah air seperti melaksanakan upacara bendera setiap hari Senin, selalu menyanyikan lagu nasional, peserta didik belajar menghafal teks pancasila, selalu menjaga akan kebersihan di lingkungan dimanapun berada dan selalu menerapkan sikap rukun dan toleransi.

4. Kerakyatan Yang Dipimpin Oleh Hikmat Kebijaksanaan Dalam Permusyawaratan Perwakilan

Penanaman nilai pancasila pada sila ini yaitu untuk para peserta didik pada saat kegiatan musyawarah untuk melakukan pemilihan pengurus kelas seperti Ketua Murid, Bendahara, dan staf lainnya oleh peserta didik, pendidik selalu membiasakan 
untuk belajar menyelesaikan permasalahan yang terjadi di kelas dengan musyawarah untuk mufakat, guru selalu menampung pendapat-pendapat dari peserta didik.

\section{Keadilan Sosial Bagi Seluruh Rakyat Indonesia}

Penerapan nilai pada sila ke lima ini yaitu pada saat kegiatan pembelajaran ataupun saat di luar ruangan guru selalu memberikan contoh penerapan sikap adil dalam segala hal, selalu mengajarkan akan toleransi. Peserta didik diharapkan selalu menerapkan sikap saling berbagai antar teman yang sedang membutuhkan.

Penerapan nilai-nilai ini pada lingkungan sekolah harus diterapkan pada lembaga pendidikan yang dasar seperti sekolah dasar, dengan berkembangnya zaman penerapan nilai pancasila serta karakter sangat dibutuhkan oleh bangsa ini maka dengan itu harus diterapkan kepada anak sedini mungkin. Lembaga pendidikan mengharapkan memiliki generasi yang sangat baik dan sangat diharapkan oleh negara, karena negara membutuhkan orang-orang atau generasi yang telah sesuai dengan aturan yang terdapat dalam Undang-Undang.

Dalam penerapan kehidupan sehari-hari pancasila tidak akan bisa diserahkan begitu saja tanpa adanya implementasi yang telah sesuai dengan aturan-aturan yang berlaku. Bila pancasila tidak diterapkan dalam kehidupan berbangsa dan bernegara akan kurang bermanfaat mengingat pancasila merupakan paradigma yang harus dijalankan dengan makna-makna yang terkandung di dalamnya (Toni \& Faisal, 2019).Paradigma pancasila berpegang pada kebangsaan, keyakinan, nilai, cita-cita dan perasaan yang menjadi sebuah landasan dasar untuk bersikap dalam kehidupan berbangsa dan bernegara.

Menurut Widodo (2019), dengan adanya era disrupsi ini akan menjadi sebuah tantangan dalam pengembangan pembelajaran di sebuah lembaga pendidikan. Masyarakat harus menyadari bahwa banyak peristiwa yang dapat dilakukan atau kegiatan yang dapat dilakukan oleh pendidik dalam mengikuti arus perkembangan zaman yang berlaku saat ini. Kolaborasi dalam menerapkan nilai pancasila dibidang pendidikan khususnya untuk seorang guru yaitu dengan peran sebagai pemberi ilmu, pembimbing dan pendidik harus dapat memberikan nilai dengan utuh melewati pembelajaran serta harus lebih berinovasi dan kreatif dalam menerapkan nilai pancasila.

Banyak sekali tantangan-tantangan yang dihadapi bagi generasi penerus di era disrupsi ini. Mengingat pada sekarang sedang terjadi sebuah wabah virus yang menyebar 
diberbagai negara tidak hanya di Indonesia saja tapi seluruh dunia terpapar wabah virus ini yang dinamakan dengan Covid-19, adanya virus ini membuat seluruh manusia melakukan semua kegiatan di rumah saja baik dari pekerjaan, pendidikan dan aktivitas lainnya. Dengan teknologi yang berkembang seluruh dunia dapat sedikit mengatasi berbagai aktivitas yang terhambat dengan menciptakan sebuah media yang dapat dipergunakan untuk kebutuhan supaya tetap menjalankan kegiatan-kegiatan aktivitas sehari-hari, seperti pada sektor pendidikan peserta didik melakukan pembelajaran dengan media seperti WhatsApp, Google Meet, Google Classroom, Zoom serta beberapa aplikasi lainnya. Sehingga penerapan pendidikan terutama nilai pancasila pada usia dini pun dapat diberikan kepada anak-anak karena selain dapat diberikan oleh kedua orang tua karena orang tua bekerja di rumah dapat memantau anak. Tetapi dengan belajar dari rumah banyak anak yang menyalah gunakan pemakaian gadget, anak-anak kerap bermain permainan di gadget dengan alasan belajar maka orang tua harus dapat memantau perkembangan anak di rumah jangan biarkan terus menerus menggunakan gadget karena itu tidak baik untuk perkembangannya.

\section{SIMPULAN}

Pancasila merupakan dasar filsafat yang mendasari akan kehidupan warga negara Indonesia, maka demikian nilai pancasila baik karakter harus tertanam dalam diri peserta didik di generasi milenial seperti pada saat ini untuk menciptakan generasi yang berakhlak mulia serta berperilaku sesuai dengan harapan yang telah ditanamkan oleh negara Indonesia. Nilai-nilai pancasila diterapkan dalam kegiatan pembelajaran supaya siswa selalu menanamkan hal kebaikan dan sikap yang sangat baik bagi dirinya sendiri maupun orang lain. Pada implementasi nilai yang telah dipaparkan diatas yang telah membahas mengenai penerapan nilai-nilai pancasila dalam proses kegiatan pembelajaran, banyak harapan yang diinginkan oleh bangsa dan negara, oleh guru dan orang tua dari peserta didik. Diharapkan guru selalu menanamkan nilai-nilai yang mendidik anak, diharapkan kepada lembaga pendidikan selalu memberikan kurikulum yang dapat membangun karakter anak pada generasi milenial seperti saat ini dan diharapkan kepada orang tua selalu membimbing anaknya ketika berada di lingkungan keluarga, masyarakat dan lingkungan rumah, serta peran orang tua agar selalu menumbuhkan sikap cinta tanah air dan kegiatan yang dapat membangun anak-anaknya.

\section{UCAPAN TERIMA KASIH}


Dengan selesainya tulisan ini saya mengucapkan banyak terima kasih kepada pihak-pihak yang bersangkutan, terutama kepada ibu dosen saya yang telah membimbing proses penulisan karya ini dan kepada para teman-teman saya yang sudah membantu saya dalam menyelesaikan penulisan ini. Sehingga penulisan ini dapat terselesaikan dengan baik, lancar dan sukses.

\section{DAFTAR RUJUKAN}

O3Tugas Pancasila 1 - Winanda Marasoli Maksum (1744390026) (1). (n.d.).Diakses dari:https://mahasiswa.yai.ac.id/v5/data_mhs/tugas/1744390026/03Tugas\%20Panc asila\%201\%20-\%20Winanda\%20Marasoli\%20Maksum\%20(1744390026).docx

Asmaroini, A. P. (2016). Implementasi Nilai-Nilai Pancasila Bagi Siswa Di Era Globalisasi. Citizenship Jurnal Pancasila Dan Kewarganegaraan, 4(2), 440. https://doi.org/10.25273/citizenship.v4i2.1077

Atiah, N. (2020). Pembelajaran Era Disruptif Menuju Masyarakat 5.0. Prosiding Seminar Nasional Pendidikan Program Pascasarjana Universitas Pgri Palembang 10 Januari 2020.

Dewi, G., \& Nur, L. (2014). Gina Dewi Lestari Nur, 2014 Pembelajaran Vokal Grup Dalam Kegiatan Pembelajaran Diri di SMPN 1 Panumbangan Ciamis Universitas Pendidikan Indonesia | repository.upi.edu | perpustakaan.upi.edu. Yoanda Amallya, 2008-2010.

Fadilah, N. (2019). Tantangan Dan Penguatan Ideologi Pancasila Dalam Menghadapi Era Revolusi Industri 4.0. Journal Of Digital Education, Communication, And Arts (DECA), 2(02). https://doi.org/10.30871/deca.v2i02.1546

Fadlila Rachman, Y. (2020). Penguatan Pancasila Sebagai The Living Ideology Melalui Revitalisasi Pembelajaran Pancasila Di Era Disrupsi. Citizenship Jurnal Pancasila Dan Kewarganegaraan, 8(2).

Hatim, M. (2020). "Implementasi Nilai Pancaila Sebagai Penanaman karakter Belajar Bagi Siswa SD Dalam Pembelajaran Daring” dalam Media Mahasiswa Indonesia: https://mahasiswaindonesia.id/implementasi-nilai-nilai-pancasila-sebagaipenanaman-karakter-belajar-bagi-siswa-sd-dalam-pembelajaran-daring/

Khosiah, N. (2020). Implementasi Nilai-Nilai Pancasila Peserta Didik Di Madrasah Ibtidaiyah Mambail Falah Tongas - Probolinggo. Al-Insyiroh: Jurnal Studi Keislaman, 6(1). https://doi.org/10.35309/alinsyiroh.v6i1.3818 
Kristiono, N. (2017). Penguatan Ideologi Pancasila Di Kalangan Mahasiswa Universitas Negeri Semarang. Harmony, 2(2).

Maulida, K.N. (2019). "Pancasila Sebagai Sistem Etika Dalam Presfektif Sosial Budaya" https://www.academia.edu/39339773/Tugas_Pancasila_Pancasila_Sebagai_Sistem Etika_Dalam_Prespektif_Sosial_Budaya

Sulianti A; Efendi Y; dan Sa'diyah H. (2020). Penerapan Nilai-Nilai Pancasila Dalam Lembaga Pendidikan.Jurnal Pancasila dan Kewarganegaraan (2020). https://doi.org/10.24269/jpk.v5.n1.2020.pp54-65.

Toni, T., \& Faisal, F. (2019). Pancasila Antara Akumulasi Informasi Dan Paradigma Kebangsaan. Progresif: Jurnal Hukum, 13(1). https://doi.org/10.33019/progresif.v13i1.1031

Wahyono, I. (2018). Implementasi Nilai-Nilai Pancasila Dalam Kegiatan Pembelajaran Di Sdn 1 Sekarsuli. In Basic Education (Vol. 7, Issue 2).

Widodo, S. T. (2019). Inovasi Pembelajaran Pendidikan Kewarganegaraan Perguruan Tinggi Dan Sekolah Dasar Dalam Menghadapi Tantangan Era Disrupsi. Jurnal Proresif UNS, 3(7). 